\title{
Optimization of Implementation QMS ISO 9001:2008 in the Education and Training Vocational Education (TVET) Professional
}

\author{
Muhammad Giatman \\ Faculty of Engineering State University of Padang, INDONESIA \\ Jalan Prof. Dr. Hamka Air Tawar, Padang, 25131, Indonesia +62 7527055644 \\ giat_5131@yahoo.co.id
}

\begin{abstract}
One of the crucial issues the nation today is the lack of consistency and commitment to long-term employment, therefore, need to be prepared and the culture of people who have a good work ethic and professional. Implementing Quality Management System (QMS) ISO 9001: 2008 with good and consistent is the right strategy to overcome these problems. This paper will explain the impact of the implementation of QMS ISO 9001: 2008 for quality improvement and work culture. This research type is based longitudinal study of secondary data from internal and external audit results. Based on the survey results revealed the implementation of QMS ISO 9001: 2008, which is supported by a full commitment to leadership and employees, will be able to change the culture of organizations and individuals to work with better and more professional.
\end{abstract}

Index Terms - implementation of QMS ISO 9001: 2008, consistency, commitment, work culture, professional.

\section{Introduction}

Key to the success of a program is determined by the readiness of the people who will implement the program. A good program if it is not supported by a good executor does not guarantee the program will run properly. Crucial issues for the Indonesian people today are not just a matter of ability and competence, but rather on the issue of workplace culture. Often found the programs that have been designed and implemented properly after some time freezes and fails again, because it is not supported by the commitment and good consistency. Therefore preparing cultured human work and good work ethic (critical, creative, innovative, commitment, consistent, and professional) need attention. This will become more important in order to win the competition in the free market of ASEAN (AFTA) and Asia Pacific (APEC) which started in 2015's. One method that has proven quite reliable in shaping the culture of this work is to implement a QMS ISO 9001: 2008 as well and consistently in every organization providers [1].

Faculty of Engineering, State University of Padang (FT UNP) is one of the institutions in charge to organize TVET programs at Diploma level (D-3, D4) Bachelor (S1), Master (S2), and $\mathrm{PhD}$ (S3). Where the product of the FT UNP will be teachers, instructors, and even managers of vocational schools (SMK). Therefore, improving the quality and profesiolalisasi FT UNP as a supplier of Human Resources for vocational personnel will determine the process of improvement and professionalization of TVET programs as a whole. From the FT UNP has sought to improve the quality of the organization by implementing QMS ISO 9001; 2008 since 2008. By studying the concept and philosophy contained in QMS ISO 9001 associated with major problems of behavior and work culture masarakat Indonesia that reality is still weak and has not been demonstrated characteristics of professional work culture, the implementation of QMS ISO 9001: 2008 can be used as a means to improve it.

Based on the findings of various studies on the implementation of the Quality Management System ISO 9001: 2008 is known that this system is quite successful repair work culture organizational culture towards a positive and productive work that is very important in order to improve the professionalism of the management of institutions that are highly competitive.

Quality is often defined as everything that satisfy customers or conformation (conformity) to the requirements or needs [2]. Furthermore, the quality can also be interpreted as a result of engineering / product / goods / services to be improved continuously (continuously quality improvement) through a guarantee (quality assurance) a strict control (quality control) assessment / assessment exact quality (quality assessment) to be able to satisfy the customer. Quality improvement, carried out continuously with the cost of production more efficient and always up to date [3]. Quality is a dynamic condition associated with products of human services and environmental processes that meet or exceed expectations.

A concept that seeks to improve the quality is Total Quality Management (TQM). In carrying out the concept of TQM is necessary to change the mindset that good in terms of quality. Mindset is a mental attitude that is formed through education, experience, and prejudice. Mindset is a mental institution used by people as a basis to behave and act. Mindset consists of three main components, namely: (1) paradigm, which means used by someone inside look at something (2) basic belief, that confidence placed by someone against something and (3) basic values, namely the attitude of the nature and character upheld high by someone that is based on the values of one's actions is limited [4].

Naisbitt shows how various contextual changes have given rise to various global paradox [5]. Only those who are able to give an appropriate response to contextual changes that can benefit from it. Instead those who wish to obtain reliability will drift hit by global changes of paradoxes it.

Quality Management System is a set of documented procedures and standard practices for the management system that aims to ensure the suitability of the process and product of the particular needs or requirements. Needs or requirements that are determined or specified by the 
customer and the organization. Lately QMS ISO 9001: 2008 is considered very important in the business world and the education system because it provides guidance to organizations on how to manage with good quality and sustainable. Enable an organization to operate effectively and efficiently, one of the tasks that must be done is to escort the leader and guide the behavior of the organization in delivering satisfaction to the people they lead. Therefore, the behavior of a very large organization can influence the achievement of the goals / vision and mission of an organization.

Behavioral science organization (organization behavior) basically studies related to aspects of human behavior within the organization or group. Organizational behavior is a field of study that investigates the impact that individuals, groups and organizational structure have on behavior within the organization, for the purpose of applying knowledge towards improving Reviews such an organizational effectiveness [6]. The three-level models to study human behavior in organizations, namely: (a) the level of the individual, (b) the level of the group, (c) the level of the organization [6]. "The field of organizational behavior has envolved from the scientific study of management during the industrial era, administrative theories of manager's role, principles of bureaucracy, and human realtions studies of employees' needs" [7]. Organizational behavior is the result of thought and research from a number of disciplines related to the interaction of human behavior within a group or organization. There are three main factors that will shape the behavior of the organization, namely Leadership, Managerial, and work culture.

Leadership is an effort to influence a lot of people through communication to achieve the goal [6] [8] [9]. The model of leadership that is suitable for quality management is the transformational leadership model [2]. The dynamic of transformational leadership involve: strong personal identification with the leader, joining in a shared vision of the future, or the self-interest goingbeyond exchange of rewards for compliance [10].

The management is the art of getting done through people [11]. Management is the art of moving people. A good manager is a manager that because experience has or find art (the art) in managing the people he leads with a distinctive style and behavior. A good manager is a manager that can optimize all resources owned by the organization efficiently, have the right strategy, effective objective SMART (Specific, Measurable, achieveable, reachble, and Timely), and able to withstand the changes that occur.

Every human being as a creature equipped to live the so-called mind or intellect, and culture (culture). Culture attached to each individual at the time of carrying out work and a culture which is believed by the group if it is implemented in continuous culture while doing the work and called the work culture. Therefore, the work culture is very important because the problem lies in the self-employment culture of each individual [12]. Work culture is a system of values that are believed by all members of the organization and are studied, applied, and developed with the work culture of an organization, which functions as well as adhesive systems and can be used as a reference to behave within the organization to achieve goals organization that has been set [13].
Therefore, the process of internalization and institutionalization of an organization's culture to the process of implementation in the contributions of all members of the organization requires understanding, regularity, should lead to the vision and mission of the organization since its main leadership levels, throughout the entire existing units.

The purpose of this study is to look at the role of implementation of QMS ISO 9001: 2008 to improve the quality of work better organization and professional.

\section{Methods}

This research type is longitudinal study, which is investigating the pattern and sequence of growth, according to a function of time. The approach used is a qualitative approach that is ex post facto. Ex post facto study was to describe and interpret the observed object in accordance with what it is without giving treatment on the object of research. The data used is secondary data, ie data from internal audit and external audit of the QMS ISO 9001: 2008 Faculty of Engineering, State University of Padang 2008-2014. The data is then analyzed through qualitative approach to explain the pattern of behavior change based on the period of time the research object.

The data used indicator is the number of findings obtained during an internal audit and external audit. In the system there are two types of audit findings, namely the nonconformity and Observation. Non-conformity, is kind of the findings stated a lack of compatibility between the SOP determined by the implementation of the field. While Observation, are suggestions for improvement that needs to be done to repair but not non-conformity.

\section{Result and Discussion}

Faculty of Engineering, State University of Padang (FT UNP) currently has 7 Department with one graduate programs, as well as 22 study programs consisting of study programs Diploma (D3, D4), Bachelor (S1), Magister (S2), and Doctor (S3). Department in question is Electrical Engineering, Electronics Engineering, Mechanical Engineering, Automotive Engineering, Civil Engineering, Mining Engineering, and Family Welfare, as well as the Graduate Program.

The number of active students \pm 6500 people, the number of lecturers: 209 people, engineers and government employees (PNS): 46 people. Besides, there are additional lecturers contracts and contract employees whose numbers adjusted to the needs and financial condition of the institution. Furthermore, in support of the implementation of the course has 29 units of the Faculty of Engineering laboratories and workshops are spread in every department and faculty.

ISO QMS was first introduced in the Faculty of Engineering UNP Padang in September 2007, through an academic seminar with the theme "Implement QMS ISO 9001: 2000 as an effort to improve the academic quality". After the leaders of faculty formed a taskforce in charge of preparing the document QMS ISO 9001: 2000 FT UNP under the guidance of consultants from P4TK Medan.

Taskforce works for \pm 4 months to prepare the document system. Tasforce is representative of Department, programs of study, faculty, which consists of elements Leader, Lecturer, technician, and Employee Administration. 
with total membership of 54 people. Dekumen generated consisting of: (1) Quality Manual, (2) Standard Operating Procedure (SOP), and (3) The operating instructions / manual operation. At first there were 71 SOP which consists of: (a) 20 basic procedures related to the core business of education and teaching institutions, (b) 39 supporting procedures, and (c) 12 procedures increase. As long as there is the addition of 6 SOP implementation, so that the total current SOP is 77 SOP (FT UNP, 2013)

The system is implemented in January 2008. After the start went well, 3 months later conducted an internal audit. Then followed a month later with an external audit by the certification agencies of TUV Rheinlad. And for the first time QMS ISO 9001: 2000 certified QMS ISO 9001: 2000 June 4, 2008 with register number 01100 086042. March 2009 re-audit conducted by the release of a new series of QMS ISO 9001: 2008. For the next year do Survelence Audit, except in February 2012 carried out a re-audit because of expiration of the previous certificate, then the beginning of 2015 will be re-audit to obtain renewal certificate back the next period.

In order to maintain consistency and quality improvement implementation of this system, it is periodic audits have been carried out two forms, namely internal audits conducted every 6 months, and external audit each year. The summary results of the internal audit since 2008 till now shown in Table 1. The internal audit conducted konperhensip to all work units in the faculty of engineering by \pm 25 internal auditors who has been certified internal auditor.

Table 1. Data from the Internal Audit

\begin{tabular}{llrrrrrr}
\hline \multirow{2}{*}{ No } & \multirow{2}{*}{ Year } & \multicolumn{3}{c}{ Non-Conformity } & \multicolumn{2}{c}{ Observation } \\
\cline { 3 - 7 } & & QNC & New & Old & UK & QO & UK \\
\hline 1 & March 2008 & 82 & 82 & 0 & 32 & 70 & 30 \\
2 & Nov 2008 & 44 & 18 & 26 & 29 & 53 & 23 \\
3 & April 2009 & 34 & 21 & 13 & 25 & 34 & 21 \\
4 & Des 2009 & 30 & 9 & 21 & 18 & 49 & 26 \\
5 & Mach 2010 & 23 & 13 & 10 & 25 & 41 & 18 \\
6 & Nov 2010 & 40 & 17 & 23 & 22 & 56 & 15 \\
7 & April 2011 & 34 & 20 & 14 & 23 & 69 & 25 \\
8 & Nov 2011 & 37 & 17 & 20 & 24 & 48 & 22 \\
9 & April 2012 & 29 & 11 & 18 & 27 & 77 & 18 \\
10 & Okt 2012 & 18 & 9 & 9 & 15 & 28 & 12 \\
11 & April 2013 & 21 & 12 & 9 & 17 & 80 & 27 \\
12 & Nov 2013 & 16 & 8 & 8 & 10 & 61 & 23 \\
13 & April 2014 & 8 & 3 & 5 & 6 & 69 & 25 \\
14 & Nov 2014 & 5 & 2 & 3 & 3 & 87 & 19 \\
\hline
\end{tabular}

In the Faculty of engineering there are 60 units that became the object of the audit system, which consists of 29 units of laboratories and workshops, 22 study programs, four administrative units, 4 leaders of faculty, and 1 unit of Management representative. Whenever the audit followed up with the Management Review Meeting, which aims to discuss and discuss the findings obtained during the audit, to obtain repair solution, which subsequently became official policy management in taking corrective action.

In the audit, there are two types of audit findings, namely the Non-Conformity (NC) which means that there is a discrepancy with implementation of the established procedure, and Observation ie suggestions for improvement system that actually does not violate the procedure but beneficial when done. QNC column in Table 2, state the number of non-conformity findings in the audit period, while the New column, stating NC new findings appear in the relevant period, while the old column, said the findings meant also been found during the audit of the previous period. Column UK, states targeted work unit audits, as described above, there are as many as 60 units of work.

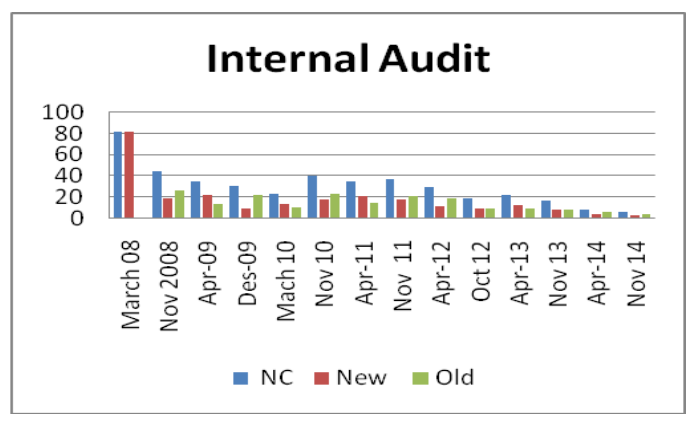

Fig. 1. Trend of the internal audit findings

Based on the above explanation, Figure 1 shows there is a tendency for the reduced number of NC findings of the audit period to the next audit period, this indicates that the improvement in the running system, although still found the same problem with the findings of the previous period, and also found new issues. Similarly, the number of work units where the discovery of $\mathrm{NC}$ also move fluctuate, but cendurung decreased, and the possibility of exchanging the position of one unit to another bias happen. This certainly indicates that the system runs dynamically occurring.

External audits carried out by the ISO certification agencies, in this case the FT UNP took the certification body TUV Rheinland Germany. External audits performed each year, the first year of audit certificates, namely to ensure that the audited organization really has implemented QMS ISO is good, so it's worth given a certificate.

Table 2. Data External Audit Results

\begin{tabular}{llrcc}
\hline No & Year & NC & Obsevation & Obser + \\
\hline 1 & 2008 & 9 & 9 & - \\
2 & 2009 & 6 & 9 & - \\
3 & 2010 & 3 & 6 & - \\
4 & 2011 & 2 & 10 & - \\
5 & 2012 & 0 & 10 & $(+5)$ \\
6 & 2013 & 1 & 8 & $(+4)$ \\
\hline
\end{tabular}

After the certificate is given, then each of periodically, at least 1 time a year do survelence audit, whose function is to ensure the system continues to run as where it should be. An external audit is usually not done thoroughly, but done through samples taken at random by the auditor. The data from the external audit are shown in Table 2.

Figure 2, shows a trend of decreased significantly from period to period, even in the period to 5 no findings $\mathrm{NC}$, but the observation increases, and offset by the positive observations. Positive observations are things that have been obtained in excess of what is demanded in the procedure and need to be maintained. 


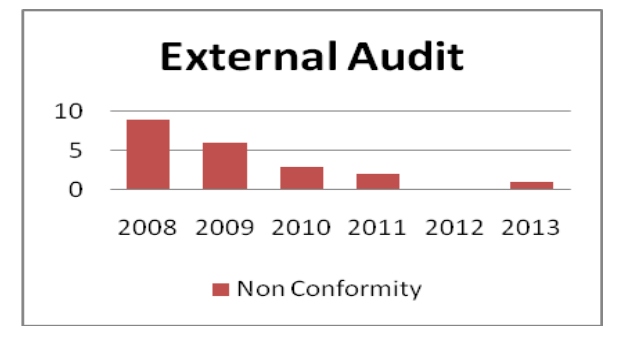

Fig. 2. Trend of the external audit findings

Implementation of QMS ISO 9001: 2008 on vocational technical education institutions (TVET), an agency strategic step in improving the quality of education gradual and sustained, especially in the aspects of the process management of the institution. Continuous quality improvement must be built through a process of systematic, planned, measured, gradual, and sustainable. QMS ISO 9001: 2008 will be able to walk well in line with expectations, if a culture of quality (quality of live) that represented the spirit of the system itself. Quality culture was formed, would not be separated from how the system was built, executed, controlled, evaluated, and treated by all of the components and the school community, so that in time the system becomes an integral part of school organizational behavior.

Based on the result of exposure, seen a tendency for positive, with declining number of audit findings, whether the internal audit and external audit. Decreasing the findings indicate the system has progressed well through a continuous improvement mechanism [2][14][15][16]. Progressed well working system would not be separated from the support and attitude of employees in carrying out the tasks and work through referrals and coaching leadership [6][17][18].

Research on the impact of the implementation of QMS ISO 9001: 2008 for organizational behavior at SMK in West Sumatra explains that there has been a positive change school organizational behavior, with the main indicators of the variables of leadership, managerial, and work culture [1]. The implementation of QMS ISO 9001: 2008 at SMK Negeri 13 Bandung positive impact on the progress of the school, where (a) the system becomes standardized and documented work, (b) ensuring that the process is conducted in accordance with defined management system, (c) spirit of employees increased because of the clarity of work and improve the efficient work, (d) the existence of a working relationship that is more clear and harmonious, (e) the standardized policies and operating procedures of the school organization, (f) the existence of a solid foundation to build attitudes and work behavior [19]. The importance of the influence of leadership, commitment and work climate in determining the effectiveness of the implementation of ISO 9001: 2008 [20].

Other findings such as [20][21][22] and others in connection with the benefits of ISO QMS implementation in an effort to improve the management system of educational institutions and increasing the quality of work culture, which in turn improves performance organization of the institution as a whole.

Thus the authors see the importance of optimizing the implementation of QMS ISO 9001: 2008 in an effort to make the program successful development of quality education institutions and vocational Technology (TVET) through the preparation of cultured human resources work and high work ethic (critical, creative, innovative, commitment, consistent, and professional). Because it is very important in order to win the Asean free market competition (AFTA) and Asia Pacific (APEC) which is about to begin in 2015 .

\section{Conclusion}

Based on the analysis and the discussion above it can be concluded that the implementation of QMS ISO in a variety of technical and vocational education institutions have been able to improve the quality of organizational management institutions, both in terms of the quality of the institution's leadership, managerial quality of schools, and the quality of the organization's work culture and depressed individuals are significant. By the need to develop implementation of QMS ISO 9001: 2008 on all units / organizations existing TVET.

\section{References}

[1] Giatman Muhammad. 2012. Quality Management System ISO 9001:2008, Organizational Behavior and The Impact on the Performance of Vocational High School in West Sumatra. Dissertation, Graduate Program, Padang State University.

[2] Gaspersz, Vincent. 2011, Total Quality Management, Untuk Praktisi Bisnis dan Industri, edisi Revisi, Vinchristo Publication, Baranangsiang, Bogor

[3] Goetsch,D.L. and Davis,S.B. 1994. Introduction to Total Quality, Quality Prodctivity, Competitiveness. Englewood: Prentice Hill International Inc. 121-138

[4] Mulyadi. 2000. Pendekatan Baru Total Quality Management. Prinsip manajemen Kontemporeruntuk Mengarungi Lingkungan Bisnis Global. Y ogjakarta: Gajah Mada. University Press

[5] Naisbitt, J. 1994. Global Pardox, New York: Warner Books

[6] Robbinss Stephen P., 2002. Essentials of Organizational Behavior (Terjemahan), Edisi Kelima, Penerbit Erlangga, Jakarta.

[7] Scott, W. R.(2002). Organization: Rational Natural, and open systems (4rd. ed.) englewood Clifts, NJ: Prentice Hall.

[8] Dubrin Andrew J., 2005. Leadership (Terjemahan), Edisi Kedua, Prenada Media, Jakarta

[9] Fiedler. 1964. A Contingency Model Of Leadership Effectiveness. New York: Academic Press.

[10] Hater, J. J., \& Bass, B. M. (1988). Superiors' evaluations and subordinates' perceptions of transformational and transactional leadership. Journal of Applied Psychology, 73(4), 695-702

[11] Mary P. Follett.2003. Creating Democracy, Transforming Management, Tonn, Joan C., New Haven: Yale University Press.

[12] Triguno. (2004). Budaya Kerja. PT Golden Terayon Press. Jakarta

[13] Moeljono Djokosantoso. 2003. Budaya Korporat dan Keunggulan Korporasi, Elex Media Komputindo, Jakarta

[14] James Lewis, Jr. 1993. Implementing Total Quality in Education. New York USA: Natonal Center to Save our Schools

[15] Sallis, Edwar. 1992. Total Quality Management and Standards in Further Education, in harry Tomlinson, ed. The search for Standards, Harlow, Longman.

[16] Visscher J. Andrie, 2009. Improving Quality Assurance in European Vocational Education and Training; Factors Influencing The Use of Quality Assurance Findings. Springer, Nederland. 
[17] Dale, B.G, 2003. Developing, Introducing and Sustaining Total Quality Management. (http://www.blackwell.publishing.com) diakses 28 Februari 2011

[18] Saraph and Sabastian. 1993. Development Quality Culture. In Berry,G. Leadership and the Development of Quality Culture in School. International Journal of Education of Management. 11-2. $52-64$

[19] Aprianto. 2010. Efektifitas Implementasi SMM ISO 9001:2008 Pada Pendidikan Kejuruan. (http://aprianto29.wordpress.com, diakses tanggal20 Oktober 2010)

[20] Susilawaty, Conny, 2005. Harapan dan Realita Penerapan Sistem Manajemen Mutu ISO 9001:2000 di Perusahaan Kontraktor. Civil Engineering Dimension, Vol 7. No.1. 30-35 March 2005. (http://puslit.petra.ac.id/journal/civil) diakses Maret 2011.

[21] Franz Santioloan, 2001. Evaluasi Implementasi Program Jaminan Kualitas (Quality Assurance Program) ISO 9001 pada PT. Sintra Sinarindo Elektrik di Jakarta. Tesis, Program Pascasarjana Undip Semarang

[22] Ida Ayu B \& Suprayetno A. (2008), Penelitian dengan judul "Pengaruh Motivasi Kerja, Kepemimpinan dan Budaya Organisasi Terhadap Kepuasan Kerja Karyawan serta Dampaknya pada Kinerja Perusahaan (Studi kasus pada PT. Pei Hai International Wiratama Indonesia). Jurnal Manajemen dan Kewirausahaan, Vol.10, no. 2, September 2008: 124-135 